\title{
Adenine Phosphoribosyltransferase Mutants in Saccharomyces cerevisiae
}

\author{
By ROBIN A. WOODS, 1* DARLENE G. ROBERTS,' \\ DAVID S. STEIN'† AND DAVID FILPULA: \\ 'Department of Biology. Unitersity' of Winnipeg. Winnipeg, Manitoba, Canada R3B 2E9 \\ 2 Department of Pediatrics, Unicersity of California, San Diego, California 92093, USA
}

(Received 31 January 1984; revised 19 April 1984)

Mutants of Saccharomyces cerevisiue deficient in adenine phosphoribosyltransferase (A-PRT, EC 2.4.2.7) have been isolated following selection for resistance to 8-azaadenine in a prototrophic strain carrying the ade4-su allele of the gene coding for amidophosphoribosyltransferase (EC 2.4 2.14). The mutants were recessive and defined a single gene, apt $I$. They did not excrete purine when combined with ade $4^{+}$. The mutants appeared to retain some A-PRT activity in crude extracts, and strains of the genotype ade 2 aptl responded to both adenine and hypoxanthine. Mutants deficient in adenine aminohydrolase (EC 3.5.4.2) activity, aahl, and hypoxanthine:guanine phosphoribosyltransferase (EC 2.4.2.8) activity, hptl, were used to synthesize the genotypes $a p t / h p t l a a h^{+}$and $a p t / h p t^{+} a a h l$. The absence of A-PRT activity in strains with these genotypes confirmed the hypothesis that the residual A-PRT activity of apt I mutants was due to adenine aminohydrolase and hypoxanthine: guanine phosphoribosyltransferase acting in concert.

\section{INTRODUCTION}

The purine phosphoribosyltransferases (PRTs) catalyse the conversion of free purine bases into their corresponding nucleotides, allowing organisms to utilize purines derived from nucleotide catabolism or available exogenously. The relationship of the reactions catalysed by these 'salvage pathway' enzymes to the pathway of purine synthesis de noto is shown in Fig. 1 . Deficiency of H :G-PRT in man results in the Lesch-Nyhan syndrome (Lesch \& Nyhan, 1964), indicating the importance of this salvage pathway of purine nucleotide synthesis.

Resistance to purine analogues has been used successfully to isolate PRT mutants in Salmonella typhimurium (Kalle \& Gots, 1961) and Schizosaccharomyces pombe (De Groodt et al., 1969). In both organisms 8-azaguanine was used to select for H:G-PRT deficiency and 2,6diaminopurine for A-PRT deficiency. Mutants of Drosophila melanogaster which are resistant to the toxic effects of exogenous purine have been shown to lack activity of A-PRT (Johnson \& Friedman, 1981). In studies with animal cells in culture 8-azaguanine has been used to select for H :G-PRT deficiency (Littlefield, 1963; Lever et al., 1974) and both 8-azaadenine and 2,6diaminopurine to select for A-PRT deficiency (Chasin, 1972, 1974; Jones \& Sargent, 1974). In contrast, failure to utilize exogenous purines was used to select PRT mutants in Escherichia coli (hpt - Chou \& Martin, 1972; apt - Jochimsen et al., 1975: gpt - Holden et al., 1976).

The PRTs of Saccharomyces ceretisiae were first investigated by Kornberg et al. (1955) who demonstrated biochemically separable A-PRT and H-PRT activity and also showed activity

† Present address: Department of Genetics, Stanford University, Stanford, California, USA.

$\ddagger$ Present address: Genex Corporation, Gaithersberg, Maryland, 20877, USA.

Abhreriations: PRT, purine phosphoribosyltransferase: A-PRT, adenine phosphoribosyltransferase; H:G.PRT, hypoxanthine:guanine phosphoribosyltransferase; AAH, adenine aminohydrolase; PRPP, 5'phosphoribosyl-1-pyrophosphate: PRPPAT, amido phosphoribosyltransferase. 


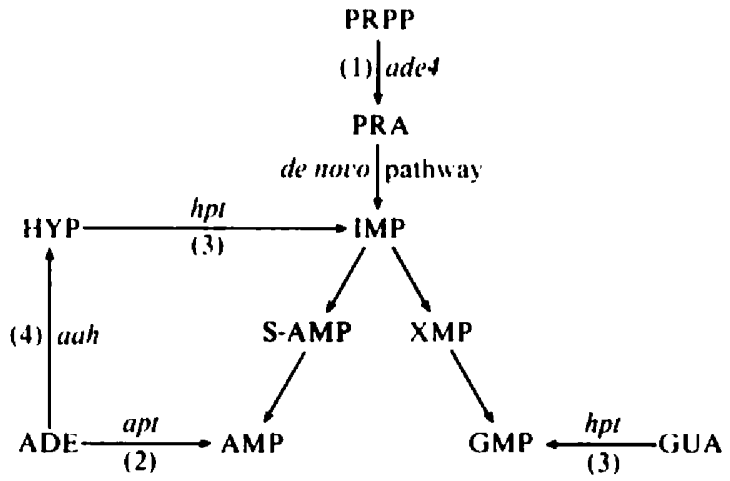

Fig. 1. Purine metabolism : de noto synthesis and the salvage pathway in $S$. ceretisiae. The enzymes and genes involved are: (1) amidophosphoribosyltransferase, ade4, EC 2.4.2.14; (2) A.PRT, aptl, EC 2.4.2.7: (3) H:G-PRT, hptl, EC 2.4.2.8; (4) AAH, aahl, EC 3.5.4.2. The pathway intermediates are as follows: PRPP, 5'-phosphoribosyl-1-pyrophosphate; PRA, phosphoribosylamine; S-AMP, succinyl-AMP: XMP, xanthosine monophosphate; HYP, hypoxanthine; ADE, adenine; GUA, guanine.

with guanine as a substrate. $\mathrm{H}$ : G-PRT has been investigated in more detail by Miller \& Bieber (1968, 1969), Schmidt et al. (1979) and Nussbaum \& Caskey (1981). Woods et al. (1983) reported that mutants defective in the activity of $\mathrm{H}:$ G-PRT were resistant to 8-azaguanine and that they excreted purines. Pickering \& Woods (1973) attempted to isolate A-PRT mutants by selecting for resistance to the adenine analogue 4-aminopyrazolo-(3,4-d)-pyrimidine; the resistant mutants defined six genes, one of which lacked a purine permease (Pickering \& Woods, 1972), but all of them retained A-PRT (Pickering, 1972). Studies by Lomax \& Woods (1969) and Pickering \& Woods (1973) have shown that 8-azaadenine is an effective inhibitor of yeast growth. We report here the use of this analogue to isolate A-PRT deficient mutants of yeast. We also show that adenine aminohydrolase (AAH) and $H: G-P R T$ can combine to form purine nucleotides from exogenous adenine and mask the metabolic consequences of A-PRT deficiency.

\section{METHODS}

Yeast strains. The genotypes and phenotypes of the primary strains of Saccharomyces cerevisiae used in this investigation are listed in Table 1 . All were from the collection of $\mathbf{R}$. A. Woods.

Media and growith conditions. The complete (YCM), minimal (YMM) and sporulation (YSM) media have been described previously (Lomax et al., 1971). Nitrogen-free medium (YCB) contained $11.7 \mathrm{~g}$ Difco Yeast Carbon Base $\mathrm{I}^{-1}$. Purines and purine analogues were added to give final concentrations as stated. Media were solidified with $1.5^{\circ}$. Difco Bacto agar. All cultures were incubated at $30^{\circ} \mathrm{C}$. Qualitative growth responses were determined using $5 \mathrm{ml}$ cultures in $15 \times 150 \mathrm{~mm}$ test tubes inoculated with $10^{5}$ cells $\mathrm{ml}^{-1}$. The cultures were incubated on a rotary shaker at 200 r.p.m. Samples were taken after $24 \mathrm{~h}$, diluted and the $\mathrm{OD}_{54}$ recorded.

Table 1. Genotypes and phenotypes of S. cerevisiae strains

\begin{tabular}{|c|c|c|}
\hline Strain & Genotype & Phenotype \\
\hline $\begin{array}{l}\text { RWI-IC } \\
\text { RWI-1D } \\
\text { RWI-4D } \\
\text { W2-1C }\end{array}$ & $\begin{array}{l}\alpha \text { ade4. } \\
\alpha \text { ade4-su } \\
\text { a ade2 ade4-su } \\
\text { ade4-su hptl.27 }\end{array}$ & $\begin{array}{l}\text { Prototroph, reduced amidophosphoribosyltransferase } \\
\text { activity*, sensitive to purine analoguest, epistatic } \\
\text { to purine excretion by pur mutants } \ddagger \text { and } h p t / \S \\
\text { Prototroph } \\
\text { As for strain } \mathrm{RW} \text { l-3B } \\
\text { Responds to adenine or hypoxanthine } \\
\text { Prototroph, lacks activity of } \mathrm{H}: \mathrm{G}-\mathrm{PRT} \S\end{array}$ \\
\hline \multicolumn{3}{|c|}{$\begin{array}{l}\text { Nieto \& Woods (1983). } \\
\text { † Lomax \& Woods (1969). } \\
\text { † Armitt \& Woods (1970). } \\
\text { § Woods et al. (1983). }\end{array}$} \\
\hline
\end{tabular}


Genetic techniques. Matings and ascus dissections were carried out as described by Ahmed \& Woods (1967). Segregants were tested for analogue resistance and nutritional requirement by replica plating. Purine excretion was detected by heavy point inoculation of strains under test onto plates of YMM agar containing a suspension of an ade 2 strain. The test plates were scored for growth of the ade 2 strain around the inocula after 2 to $4 \mathrm{~d}$. Mutants were induced by UV irradiation of RWI-ID ( $x$ ade4-su) to $10^{\circ}$ o survival.

Detection of $A A H$ actirity. AAH activity was scored by inoculating $5 \mathrm{ml}$ YCB plus adenine (0.3 mM) with a loopful of cells and incubating cultures as above for 24 to $36 \mathrm{~h}$. The cultures were then centrifuged and the optical density of the supernatant scanned over the range of 210 to $300 \mathrm{~nm}$. Strains with AAH activity hydrolyse adenine $\left(\lambda_{\text {max }} 260 \mathrm{~nm}\right)$ to hypoxanthine $\left(\lambda_{\mathrm{ma}}, 248 \mathrm{~nm}\right)$.

Preparation of cell-free extracts and assay of PRT activity. Cultures were grown from an initial inoculum of $10^{5}$ cells $\mathrm{ml}^{-1}$ in $250 \mathrm{ml}$ triple-baffled conical flasks containing $50 \mathrm{ml}$ YMM and harvested in mid-exponential phase by centrifugation after $18 \mathrm{~h}$. The cells were washed once in cold extraction buffer [ $10 \mathrm{~mm}$-potassium phosphate (pH 6.8); 0-25 M-sucrose: $10 \mathrm{~mm}$-dithiothreitol; $I^{\circ}{ }_{\circ}(\mathrm{v} / \mathrm{v})$ isopropanol $]$ and resuspended in the same buffer at $1.0 \mathrm{ml}$ per $20 \mathrm{ml}$ starting culture. An equal volume of glass beads ( $400 \mu \mathrm{m}$ diameter) was added and the mixture vortexed at top speed on a table-top vortex mixer for four periods of $30 \mathrm{~s}$ separated by $30 \mathrm{~s}$ cooling on ice. The homogenates were pipetted off and centrifuged at 12000 r.p.m. for $12 \mathrm{~min}$ in a Beckman Microfuge. The supernatants were assayed for PRT activity by the procedure of Mulligan \& Berg (1980). The assay mixture contained $100 \mathrm{~mm}-$ Tris $/ \mathrm{HCl}$ (pH 8.0), $10 \mathrm{~mm}-\mathrm{MgCl}_{2}, 1.5 \mathrm{~mm}$-cold purine. $0.5 \mu \mathrm{Ci}(18.5 \mathrm{kBq})$ [ $\left.{ }^{+4} \mathrm{C}\right] \mathrm{purine}$. I mm-dithiothreitol, $0.5 \mathrm{mg} \mathrm{ml}^{-1}$ bovine serum albumin (Sigma, fraction $\mathrm{V}$ ), and $1.0 \mathrm{mg} \mathrm{ml}^{-1} 5$-phosphoribosyl-1-pyrophosphate (PRPP). The reaction was started by adding $25 \mu \mathrm{l}$ extract to $100 \mu \mathrm{l}$ assay mixture, incubated at $37^{\circ} \mathrm{C}$ for $30 \mathrm{~min}$, and terminated by spotting $25 \mu \mathrm{l}$ samples onto $2.5 \mathrm{~cm}$ discs of DE-81 paper. Discs were washed six times in $2110 \mathrm{~mm}$ $\mathrm{NaCl}$ to remove unreacted purine, leaving the nucleoside monophosphates bound to the disc. Dried discs were counted in $10 \mathrm{ml}$ Scinti-Verse (Fisher) at $76^{\circ}$ efficiency in a Beckman LS 7500 liquid scintillation counter. Enzyme activities were determined as nmol purine nucleoside monophosphate formed $\min ^{-1}$ (mg protein) 1 . Protein concentrations were determined according to the procedure of Bradford (1976). using the Bio-Rad proteinassay reagent.

Electrophoresis and assay of PRT actitity. Fxtracts were electrophoresed on slab gels containing $8 \cdot 0^{\circ}{ }_{0}(w / v)$ acrylamide, $0 \cdot 4^{\circ}{ }_{0}(w / v) N . N$-methylenebisacrylamide, $0 \cdot 2 \mathrm{~m}$-Tris $/ \mathrm{HCl}(\mathrm{pH} 8.6)$ and $5^{\circ}{ }_{\mathrm{o}}(\mathrm{v} / \mathrm{v}) \mathrm{glycerol}$ at $4 \mathrm{C}$. The running buffer was $0.2 \mathrm{M}$-Tris $\mathrm{HCl}$ (pH 8.6). $1 \mathrm{~mm}-\beta$-mercaptoethanol. PRT activity was detected by overlaying the gels with Whatman $3 \mathrm{MM}$ paper soaked in a reaction mixture containing $100 \mathrm{mM}$ - Tris/ $\mathrm{HCl}$ (pH $8 \cdot 0$ ), $10 \mathrm{mM}$ $\mathrm{MgCl}_{2}, 2 \mathrm{~mm}$-PRPP. I mM-dithiothreitol, $5 \mu \mathrm{M}$-purine and $\left.0 \cdot 2 \mu \mathrm{Ci} f^{1+} \mathrm{C}\right)$ purine $\mathrm{ml}^{-1}$. The gel and paper were wrapped in plastic wrap and incubated for $1 \mathrm{~h}$ at $30{ }^{\circ} \mathrm{C}$. The paper was then removed and the gels soaked in $100 \mathrm{~mm}-\mathrm{LaNO}_{3}, 100 \mathrm{~mm}$-Tris $/ \mathrm{HCl}(\mathrm{pH} 7.0)$ for $1 \mathrm{~h}$. They were then washed in deionized water for $1.5 \mathrm{~h}$ and processed for gel fluorography by the procedures of Bonner \& Laskey (1974) and Laskey \& Mills (1975).

Assay of AAH. AAH activity in cell-free extracts was measured by a modification of the method described by Abbondandalo et al. (1971). Cultures were grown for $18 \mathrm{~h}$ in YMM medium from an initial inoculum of $10^{\varsigma}$ cells $\mathrm{ml}^{-1}$, harvested and resuspended in homogenizing buffer $(\mathrm{pH} 7.0)$ containing $0.1 \mathrm{M}$-phosphate buffer, $1.0 \mathrm{~mm}$ EDTA and $1 \mathrm{~mm}-\beta$-mercaptoethanol. The procedure for homogenization was as for the PRT assays. The assay mixture $(100 \mu \mathrm{l})$ consisted of homogenizing buffer containing $1.5 \mathrm{~mm}$-adenine and $1.0 \mu \mathrm{Ci}\left[{ }^{1+} \mathrm{Cladenine} \mathrm{ml}^{-1}\right.$. The reaction was initiated by the addition of $20 \mu \mathrm{l}$ cell-free extract, and terminated after $20 \mathrm{~min}$ at $37^{\circ} \mathrm{C}$ by spotting $5 \mu \mathrm{l}$ samples onto sheets of 1.3255 cellulose (Eastman Kodak) with cold carrier adenine and hypoxanthine. The chromatograms were developed in $0.1 \mathrm{M}$-sodium phosphate buffer $(\mathrm{pH} 6.8) / \mathrm{saturated}$ aqueous $\left(\mathrm{NH}_{4}\right) \mathrm{SO}_{4} / n$-propanol $(100: 60: 2$, by vol.) (solvent C. Ciardi \& Anderson, 1968). The purines were visualized under UV light, cut out and counted in $10 \mathrm{ml}$ Scinti-verse.

Chemicals and supplies. Purines, purine analogues, dithiothreitol, PRPP. Tris/ $\mathrm{HCl}$ and bovine serum albumin were purchased from Sigma. $\left[{ }^{+} \mathrm{C}\right]$ Adenine was purchased from New England Nuclear and Amersham; $\left[{ }^{1+}\right.$ C $]$ hypoxanthine was purchased from New England Nuclear. Scinti-Verse scintillation fluid and DE-81 discs were purchased from Sigma [ $\left.{ }^{+} \mathrm{C}\right]$ Adenine was purchased from New England Nuclear and Amersham: Rad.

\section{RESULTS AND DISCUSSION}

\section{Isolation and characterization of mutants}

Strains carrying the variant form of amidophosphoribosyltransferase specified by the allele ade4-su (Nieto \& Woods, 1983) have been shown to be more sensitive to purine analogues, including 8-azaadenine, than those carrying ade4+ (Pickering \& Woods, 1973). Accordingly, strain RW I-1D was mutagenized with UV light and plated onto YMM agar supplemented with 0.37 mM-8-azaadenine. Forty eight resistant mutants were isolated. The mutants were tested for growth over $24 \mathrm{~h}$ in YMM plus 8-azaadenine and YMM plus 8-azaguanine; it was expected that 
A-PRT deficiency would result in resistance to the adenine analogue only. Twelve mutants which were resistant to 8-azaadenine but sensitive to 8-azaguanine were selected for further analysis.

All of the mutants were crossed to RWI-3B ( $a$ ade4-su). They were all clearly recessive, since on YMM agar supplemented with $0.37 \mathrm{mM}$-8-azaadenine the heterozygous diploid grew less vigorously than the haploid mutants. Tetrad analysis was carried out on the cross involving mutant 9 (cross 1 , W6, in Table 2). Resistance to 8-azaadenine segregated $2: 2$ in five complete tetrads. An 8-azaadenine resistant segregant, W6-1 A, was crossed to the other 11 mutants. All of the diploids were resistant to 8-azaadenine. Eight complete tetrads from the crosses of W6-1 A to each of the mutants $8,10,11$ and 23 were dissected and analysed; all of the progeny were resistant to 8-azaadenine. Thus the 12 mutants represent a single gene, apt $l$.

\section{Genetic and biochemical analysis}

The $12 \mathrm{aptl}$ mutants were assayed for activity of A-PRT as described in Methods. The results (Table 3) show that all appeared to retain some A-PRT activity. Relative to that in the parent strain, the levels ranged from $20 \%$ in apt 1.9 to $48 \%$ in apt $l .10$.

In other systems, resistance to the adenine analogues 2,6-diaminopurine and 8-azaadenine results in complete loss of A-PRT activity (Kalle \& Gots, 1961; De Groodt et al., 1969). We hypothesized that the residual activity in our mutants could be due to adenine aminohydrolase and $H: G-P R T$ acting in concert as follows:

$$
\text { Adenine } \stackrel{\begin{array}{c}
\text { Adenine } \\
\text { aminohydrolase }
\end{array}}{\longrightarrow} \text { Hypoxanthine }
$$

The IMP formed would bind to the DE- 81 discs used in the radioassay and result in apparent APRT activity.

The hypothesis was tested in three ways. (a) Production and characterization of a strain with the genotype aptl hptl. (b) Isolation of an AAH deficient mutant, aah, and construction of the genotype aptl aah. (c) In situ assay of PRT activities following electrophoresis of cell-free extracts of appropriate genotypes.

A strain of the genotype ade4-su hptl is resistant to 8 azaguanine but not to 8-azaadenine (Woods et al., 1983). The segregant W6-2B ( $\alpha$ ade4-su apt1.9) was crossed to W2-1C (a ade4su hpt 1. 27). Analysis of eight tetrads from this cross (cross 2, W20, in Table 2) showed that eight segregants were resistant to both analogues, eight to 8-azaadenine and eight to 8-azaguanine; the remaining eight were sensitive to both compounds. The genotype of a doubly resistant segregant, presumed to be apt I hptl, was confirmed by backcrossing to RW 1-3B (ade4-su) (cross 3, W 32, in Table 2). The results of these two crosses indicated that aptl was not linked to hptl; the recombination frequencies were $50 \%$ and $54 \%$, respectively.

The results of assaying for PRT activities in appropriate genotypes derived from the cross W20 are listed in Table 4. It can be seen that A-PRT activity was reduced in aptl.9 $\mathrm{hpt}^{+} \mathrm{aah}^{+}$, and absent in aptl.9 hptl.27 aaht. The pattern of $\mathrm{H}: \mathrm{G}-\mathrm{PRT}$ activity was as expected. Thus, H:G-PRT activity is necessary for the aptl mutants to show residual A-PRT activity.

The strain W6A-3B (a ade2 aptl .9), a segregant obtained from cross 5 in Table 2, was used as the starting point for the isolation of an aah mutant. It was mutagenized and plated onto YMM agar plus hypoxanthine and, after $24 \mathrm{~h}$ incubation, replica-plated onto YMM agar plus adenine. One mutant which responded to hypoxanthine but not to adenine was obtained. It was crossed to W6-2C ( $\alpha$ ade4-su) and six complete tetrads were tested for the segregation of ade2, apt I and aahl (cross 4, DSI, in Table 2). In each tetrad two segregants showed the expected phenotype of AAH deficiency, failure to reduce the $\lambda_{\max }$ of YCB medium supplemented with adenine from $260 \mathrm{~nm}$ to $248 \mathrm{~nm}$. Segregants with the presumptive genotypes aptl.9 aahl and aahl were backcrossed to ade4-su and their identities confirmed. 
A-PRT mutants of $S$. cerevisiae
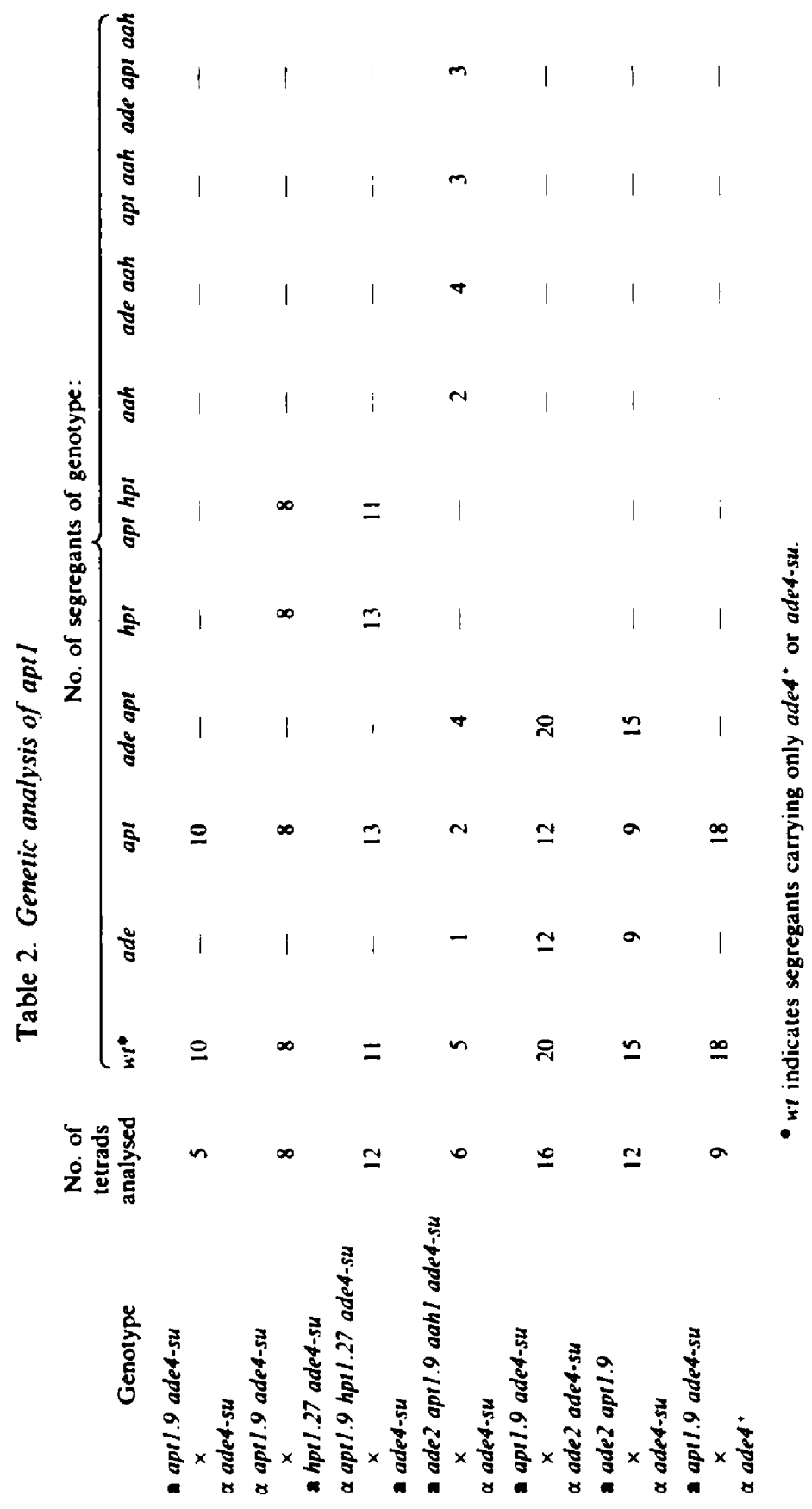

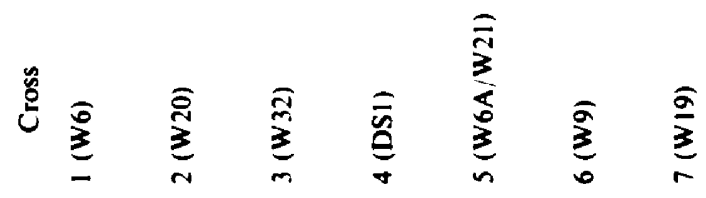


Table 3. Adenine phosphoribosyltransferase activity in mutants allocated to aptI

\begin{tabular}{|c|c|c|}
\hline Genotype & $\begin{array}{l}\text { Specific } \\
\text { activity* }\end{array}$ & $\begin{array}{l}\text { Activity relative } \\
\text { to ade4-su }(\%)\end{array}$ \\
\hline ade4-su & 24.1 & 100 \\
\hline aded ${ }^{+}$ & $28 \cdot 7$ & 119 \\
\hline$a p t 1.8$ & 8.4 & 35 \\
\hline apt 1.9 & 4.9 & 20 \\
\hline aptl.10 & 11.7 & 48 \\
\hline aptl.II & 10.9 & 45 \\
\hline$a p t l .23$ & $10 \cdot 4$ & 43 \\
\hline apt I.27 & 7.7 & 32 \\
\hline aptl.30 & 5.1 & 21 \\
\hline apt I.40 & $6 \cdot i$ & 25 \\
\hline aptl.4I & 10.3 & 43 \\
\hline$a p t l .42$ & 8.8 & 36 \\
\hline apt 1.44 & $10 \cdot 2$ & 42 \\
\hline apt l.46 & 10.3 & 43 \\
\hline
\end{tabular}

- Activities are expressed as nmol AMP formed $\min ^{-1}$ (mg protein) ${ }^{-1}$.

Table 4. Purine phosphoribosyltransferase and adenine aminohydrolase activities

\begin{tabular}{|c|c|c|c|}
\hline \multirow[b]{2}{*}{ Genotype } & \multicolumn{3}{|c|}{ Specific activity* } \\
\hline & A-PRT & H : G-PRT & AAH \\
\hline$a p t^{+} h p t^{+} a a h^{+}$ & $11 \cdot 8$ & $11 \cdot 1$ & 122.5 \\
\hline$a p t l .9 \mathrm{hpt}^{+} a \mathrm{ah}^{+}$ & $3 \cdot 4$ & 13.7 & $122 \cdot 9$ \\
\hline aptl.9 hptl.27 aah* & $0 \cdot 1$ & 0.0 & $109 \cdot 2$ \\
\hline aptl.9 hpt ${ }^{+}$aahl & 0.0 & - & - \\
\hline$a p t^{*} h p t l .27 \mathrm{aah}^{*}$ & $9 \cdot 1$ & 0.1 & 144.0 \\
\hline$a p t^{+} h p t^{+} a a h l$ & 7.8 & $\ldots$ & 0.0 \\
\hline
\end{tabular}

- Activities are expressed as $\mathrm{nmol}$ product formed $\mathrm{min}^{-1}$ (mg protein) ${ }^{-1}$.

The results of assaying for $\mathrm{AAH}$ activity in appropriate strains are listed in Table 4. It can be seen that the $a a h /$ mutant lacked activity of the enzyme. Previous studies (Roush \& Saeed, 1960; Medhat, 1965) have indicated that AAH is an inducible enzyme in yeast. Our results show that activity is high in extracts prepared from cultures in mid-exponential phase: further studies ( $R$. A. Woods \& B. P. May, unpublished results) suggest that activity is negligible in nitrogenstarved cultures and is induced by both adenine and ammonium.

The results of assay for A-PRT in strains of the genotypes aptl.9 $\mathrm{hpt}^{+}$aahl and $a p t^{+} h p t^{+} a a h l$ are listed in Table 4. It can be seen that AAH is also necessary for expression of residual A-PRT activity in the apt mutants.

A comparison of the electrophoretic mobility of the residual A-PRT activity in the mutant aptl 9 with bona fide A-PRT from the parent strain apt ${ }^{+}$ade4-su is shown in Fig. 2. The lower mobility of the residual activity was also demonstrated in apt 1.8 , apt I.23, apt 1.27 , and apt 1.30 strains (not shown). It is unlikely that this residual activity is due to mutational alteration of APRT since it showed the same mobility relative to A-PRT from ade4-su in all five mutants.

Assays for A-PRT, H:G-PRT, and H:G-PRT + A-PRT were then carried out on the same gel. $H$ : G-PRT had a lower mobility than A-PRT, as shown by the simultaneous assay of both enzymes with an extract from an $a p t^{+} h p t^{+}$aah strain. An A-PRT activity band was detectable

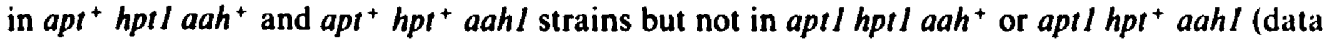
not shown). These results are consistent with our hypothesis and suggest that the residual APRT activity in the apt mutants is probably the result of $H:$ G-PRT using hypoxanthine formed from adenine by the action of AAH.

The phenotypic characteristics of the apt mutants were checked by crossing ade4-su apt 1.9 to RW1-4D (ade2 ade4-su). This is listed as cross 5 (W6A/W21) in Table 2. The accumulation of 


$\begin{array}{lllll}1 & 2 & 3 & 4 & 5\end{array}$

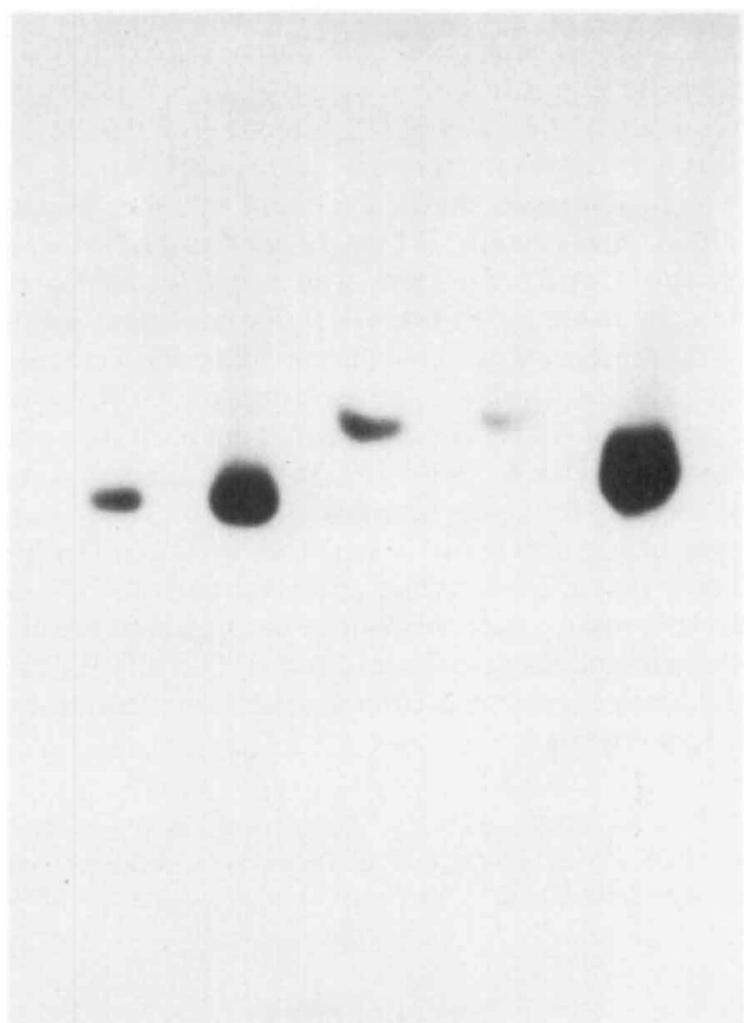

Fig. 2. Electrophoresis and the in situ assay of A-PRT in extracts from aptl. 9 and apt ${ }^{*}$ ade4-su strains. Tracks I, 2, and 5, apt ${ }^{+}$ade4-su (3, 7.6 and $30 \mu \mathrm{g}$, respectively): (racks 3 and 4, apt $I .9$ (each $344 \mu \mathrm{g}$ ). Extracts were applied to the gel in a total volume of $20 \mu \mathrm{l}$.

the red pigment characteristic of ade 2 mutants is reduced by adenine supplementation (Armitt \& Woods, 1970). The phenotypes of ade 2 and ade 2 apt 1.9 could be distinguished on YMM and YCM agar media supplemented with $0.15 \mathrm{~mm}$-adenine. The ade 2 mutant grew well on these media and was pink whereas ade 2 apt 1.9 grew poorly and was not pigmented. Burns (1964) has shown that pigment accumulation is dependent on purine nucelotide levels and has suggested that IMP is the most important inhibitor of PRPPAT in tivo. A-PRT deficiency would be expected to result in reduced levels of AMP and continued pigment accumulation. However, the combined activities of AAH and H :G-PRT would result in high levels of IMP in an ade 2 apt mutant since these enzymes would be the only route for adenine utilization. This, coupled with the poor growth of such mutants, most probably accounts for the lack of pigment accumulation.

To confirm the genotype assignments the tetrads were grown in YMM and YMM plus $1.5 \mathrm{~mm}$-adenine. In the latter medium the ade 2 mutant gave a tenfold greater yield of cells than the ade 2 aptl mutant after $24 \mathrm{~h}$; however, after $48 \mathrm{~h}$, by which time the cultures were in stationary phase, the yields of both mutants were the same. In those tetrads in which both of the adenine-requiring segregants were identified as ade 2 aptl neither of the prototrophs was resistant to 8-azaadenine. The identity of the double mutants was confirmed by the presence of 8-azaadenine-resistant segregants in tetrads obtained from a backcross of a presumptive ade 2 aptl to ade4-su (cross 6, W9, in Table 2). The results of these reciprocal crosses show that ade 2 and apt $I$ are not linked. The frequency of recombinant genotypes was $63 \%$ in cross 5 and $38^{\circ}$. in cross 6.

Purine excretion has been shown to be a consequence of H:G-PRT deficiency in man 
(Rosenbloom et al., 1968), Schizosaccharomyces pombe (De Groodt et al., 1969) and yeast (Woods et al., 1983). A-PRT deficiency in man results in the accumulation of 2,8-dihydroxyadenine (Cartier \& Hamet, 1974; Doppler et al., 1981) but purine excretion has not been reported as a characteristic of the genetic lesion in either mammalian cell lines (Chasin, 1972; Jones \& Sargent, 1974) or Schizosaccharomyces pombe (De Groodt et al., 1969). The apt mutants did not appear to excrete purines when tested for crossfeeding to an ade2 strain. However, they had been induced in ade4-su, which suppresses purine excretion by other mutants (Armitt \& Woods, 1970; Woods et al., 1983). Accordingly, W6-1A (a ade4-su aptl .9) was crossed to RW 1-4A, which carries the allele ade ${ }^{+}$, and the progeny were tested for analogue resistance and purine excretion (cross 7, W19, in Table 2). Resistance to 8-azaadenine segregated $2: 2$ in the nine tetrads tested. None of the segregants excreted purines and none were resistant to 8-azaguanine.

Most of the previous studies involving the isolation of A-PRT mutants have been with organisms which lack activity of AAH. The enzyme has not been shown to occur in $E$. coli and is not present in animal tissues (Zielke \& Suelter, 1975). Thus, direct selection of deficient mutants was possible either by selecting for analogue resistance, as in Salmonella typhimurium (Kalle \& Gots, 1961), or failure to utilize exogenous adenine, as in $E$. coli (Jochimsen et al., 1975). De Groodt et al. (1969) noted that a 2,6-diaminopurine-resistant, A-PRT-deficient mutant of the fission yeast, Schizosaccharomyces pombe, responded to exogenous adenine and ascribed this to the combined activity of adenine aminohydrolase and $H:$ G-PRT. We have shown conclusively that the activities of these two enzymes can interfere with the identification of A-PRT-deficient mutants in Saccharomyces cerevisiae.

This work was supported by an NSERC grant, no. A6566, to R. A. Woods. D. Filpula was supported by Fellowship Training Grant, PHS * 5 T32 CAO920. D. S. Stein was the recipient of an NSERC Undergraduate Summer Research Award. We would like to thank Bruce May for assistance with some of the experiments.

\section{REFERENCES}

Abbondandalo, A., Weyer, A., Heslot, H. \& LAMBERT, M. (1971). Study of adenine aminohydrolase in the yeast Schizosaccharomyces pombe. Journal of Bacteriology 108, 959-963.

AhMED, K. A. \& Woods, R. A. (1967). A genetic analysis of resistance to nystatin in Saccharomyces ceretisiae. Genetical Research 9, 179-193.

ARMIT, S. \& WoODs, R. A. (1970). Purine excreting mutants of Saccharomyces cerevisiae. 1 . Isolation and genetic analysis. Genetical Research 15, 7-17.

BONNER, W. M. \& LASKeY, R. A. (1974). A film detection method for tritium labelled proteins and nucleic acids in polyacrylamide gels. European Journal of Biochemistry 46, 83-88.

BradFord, M. M. (1976). A rapid and sensitive method for the quantitation of microgram quantities of protein utilising the principle of protein-dye binding. Analytical Biochemistry 72, 248-254.

BurNs, V. W. (1964). Regulation of purine biosynthesis and its relation to transient changes in intracellular nucleotide levels. Biophysical Journal 4, 151-166.

Cartier, P. \& Hamet, M. (1974). Une nouvelle maladie métabolique: le déficit complet en adenine phosphoribosyltransférase avec lithiase de 2,8-djhydroxyadenine. Compte rendus de l'Académie des sciences, Paris D279, 883-886.

Chasin, L. A. (1972). Non-linkage of induced mutations in Chinese hamster cells. Nature New Biology 240, 50-52.

Chasin, L. A. (1974). Mutations affecting adenine phosphoribosyl transferase activity in Chinese hamster cells. Cell 2, 37-4I.

Chou, J. Y. \& Martin, R. G. (1972). Purine phosphoribosyltransferases of Salmonella typhimurium. Journal of Bacteriology 112, 1010-1013.

Ciardi, J. E. \& Anderson, E. F. (1968). Separation of purine and pyrimidine derivatives by thin layer chromatography. Analytical Biochemistry 22, 398408.

De Groodt, A., Heslot, H., Poirier, L., Pourquie, J. \& NAGY, M. (1969). La specificité des phosphorylases des nuclétides puriques chez le Schizosaccharomyces pombe. Compte rendus de l'Académie des sciences, Paris D269, 143!-1433.

Doppler, W., Hirsch-Kauffmann, M., Schabel, F. 2 Schweiger, M. (1981). Characterisation of the biochemical basis of a complete deficiency of adenine phosphoribosyl transferase. Human Genetics 57, 404-410.

Holden, J. A., Harriman, P. D. \& Wall, J. D. (1976). Escherichia coli mutants deficient in guanine : $x$ anthine phosphoribosyltransferase. Joumal of Bacteriology 126, 1141-1148.

Jochimsen, B., NYomad, P. \& VestergaArd, T. (1975). Location on the chromosome of Escherichia coli of genes governing purine metabolism. Molecular and General Genetics 143, 85-91.

Johnson, D. H. \& Friedman, T. B. (1981). Purine resistant mutants of Drosophila melanogaster are adenine phosphoribosyltransferase deficient. Science 212, 1035-1036. 
Jones, G. E. \& SArgent, P. A. (1974). Mutants of cultured Chinese hamster cells deficient in adenine phosphoribosyl transferase. Cell 2, 43-45.

Kalle, G. P. \& Gots. J. S. (1961). Mechanism of resistance to 2,6-diaminopurine in Salmonella typhimurium. Biochimica et biophysica acta 51, 130 . 137.

Kornberg, A., Lieberman, I. \& Simms, E. S. (1955). Enzymatic synthesis of purine nucleotides. Journal of Biochemistry 215, 417-427.

LASKEY, R. A. \& MILLS, A. D. (1975). Quantitative film detection of ${ }^{3} \mathrm{H}$ and ${ }^{1+} \mathrm{C}$ in polyacrylamide gels by fluorography. European Journal of Biochemistry 56, 335-341.

LESCH, M. \& NyHAN, W. L. (1964). A familial disorder of uric acid metabolism and central nervous system function. American Journal of Medicine 39, 561570.

Lever, J. E., Nuki, G. \& Seegmiller, J. E. (1974). Expression of purine overproduction in a series of 8azaguanine-resistant diploid human lymphoblast lines. Proceedings of the National Academy of Sciences of the United States of America 71, 2679-2683.

LiTtLEFIELD, J. W. (1963). The inosinic acid pyrophosphorylase activity of mouse fibroblasts partially resistant to 8-azaguanine. Proceedings of the National Academy of Sciences of the United States of America So, 568-576.

Lomax, C. A. \& Woods, R. A. (1969). Mutant of yeast sensitive to 2,6-diaminopurine. Journal of Bacteriology 100, 817-822.

Lomax, C. A., Gross, T. S. \& Woods, R. A. (1971). New mutant types at the ade 3 locus of Saccharomyces cerevisiae. Journal of Bacteriology 107. 17.

Medhat, P. (1965). Purification and properties of adenine deaminase from Saccharomyces ceretisiae. PhD thesis, Illinois Institute of Technology, USA.

MilleR, R. L. \& Bieber, A. L. (1968). Purification and properties of inosine monophosphate:pyrophosphate phosphoribosyltransferase (EC 2.4.2.8) from brewers yeast. Biochemistry 7, 1420-1426.

Miller, R. L. \& Bieber, A. L. (1969). Substrate binding specificity and properties of inosine monophosphate:pyrophosphate phosphoribosyltransferase (EC 2.4 2. 8) from brewers yeast. Biochemistry 8 , 603-608.

Mulligan, R. C. \& Berg, P. (1980). Expression of a bacterial gene in mammalian cells. Science 209. $1422-1427$

NiETo, D. J. \& Woods, R. A. (1983). Studies on mutants affecting amidophosphoribosyltransferase activity in Saccharomyces ceretisiae. Canadian Journal of Microbiology 29, 681-688.

Nussbaum, R. L. \& Caskey, C. T. (1981). Purification and characterisation of hypoxanthine-guanine phosphoribosyltransferase from Saccharomyces ceretisiae. Biochemistry 20, 4584-4590.

PICKerING, W. R. (1972). Studies on purine metabolism in wild type and analogue resistamt mutants of Saccharomyces cererisiae. PhD thesis, University of Sheffield, UK.

Pickering, W. R. \& Woods, R. A. (1972). The uptake and incorporation of purines by wild-type Sacccharomyces cererisiae and a mutant resistant to 4aminopyrazolo-(3,4-d)-pyrimidine. Biochimica et biophysica acta 264. 45-48.

PiCKeRING, W. R. \& WoOds, R. A. (1973). Genetics of resistance to 4-aminopyrazolo-(3,4-d)-pyrimidine in Saccharomyces cerevisiae. Molecular and General Genetics 123, 231-242.

Rosendloom, F. M., Henderson, J. F., Kelley, W. N. \& Seegmiller, J. E. (1968). Accelerated purine synthesis de novo in skin fibroblasts deficient in hypoxanthine-guanine phosphoribosyltransferase activity. Biochimica et biophysica actu 166, 258-260.

Roush, A. H. \& SAEED, M. (1960). Adenine metabolism in Saccharomyces cerevisiae. Adenase from bakers' yeast. Biochemical and Biophysical Research Communications 2, 43-47.

SCHMIDT, R., WeIGAND, H. \& ReIChert, U. (1979). Purification and characterisation of the hypoxanthine-guanine phosphoribosyltransferase from Saccharomyces ceretisiae. European Journal of Biochemistry 93, 355-361.

WoOds, R. A., Roberts, D. G., Freidman, T., Jolty, D. \& FilpulA, D. (1983). Hypoxanthine:guanine phosphoribosyltransferase mutants in Saccharo. myces cerevisiae. Molecular and General Genetics 191, 407-412.

Zielke, C. L. \& Suelter, C. H. (1971). Purine, purine nucleoside, and purine nucleotide aminohydrolases. In The Enzymes, 3rd edn, vol. 5, pp. 47-78. Edited by P. D. Boyer. New York \& London : Academic Press. 